Jurnal

Manajemen Kesehatan Indonesia

Volume 7

Nomor 1

April 2019

\title{
Pengembangan Sistem Informasi Pencatatan dan Pelaporan Status Gizi Balita Stunting di Kelurahan Gajahmungkur
}

\author{
Wahyu Indri Susanti*, Aris Puji Widodo **, Sri Achadi Nugraheni*** \\ *)Mahasiswa Konsentrasi Sistem Informasi Manajemen Kesehatan Program Studi Magister Ilmu \\ Kesehatan Masyarakat Universitas Diponegoro, \\ ** Fakultas Sains dan Matematika, Universitas Diponegoro, Semarang \\ *** Fakultas Kesehatan Masyarakat, Universitas Diponegoro, SemarangEmail : \\ wahyuindrisusanti@gmail.com
}

\section{ABSTRACT}

Stunting is a chronic nutritional problem that has an impact on growth failure in toddlers, so these toddlers tend to be shorter than the age. Monitoring of child development can be pursued with the activities of a posyandu. The role of posyandu cadres besides to motivate parents for mindfulness the importance of monitoring their height and weight measurements, also has a role in the process writing and reporting the results of weighing toddlers to the health center. With good collaboration between the community, Posyandu cadres and puskesmas can produce accurate, precise, fast, and correct data.

The purpose of this study is to develop an information system for recording and reporting on nutritional status of stunting children to support monitoring and management of nutritional status of toddlers. The method used in system development is FAST, and uses the Action Research research design with a cross sectional approach. The process of collecting the data was undertaken with the observations and in depth interviews. The subject of study were the 1 health center and nutrition officer, 1 regional counseling midwife, and 13 posyandu cadres toddler in Gajahmungkur village. Design of input, process, and output designs adjusted to the needs of information system users.

It can be concluded that the development of information systems for recording and reporting on the nutritional status of stunting toddlers "mozita" can help overcome problems that arise, by being able to be accessed online so that it can help the process of entering data and reporting accurately, precisely, quickly, and correctly

Keywords : Information System Development; FAST; Stunting.

\section{PENDAHULUAN}

Bentuk pembangunan dalam bidang kesehatan saat ini berfokus pada empat program utama, yang salahsatu program tersebut adalah dengan menurunya angka prevalensi balita pendek atau stunting. ${ }^{1}$ Pada tahapan anak usia balita merupakan suatu tahapan perkembangan anak yang rawan 
akan status gizi, sehingga memerlukan perhatian khusus dalam pemenuhan gizi bagi tubuh dan kesehatannya. ${ }^{2}$

Prevalensi dunia terhadap kejadian stunting menurut WHO (World Health Organization) pada balita terhitung cukup tinggi yaitu 165 juta kasus atau 26\%. ${ }^{3}$ Disamping itu Indonesia juga masih perlu memperhatikan kejadian kasus stunting balitanya, karena menurut hasil PSG 2016 (Pemantauan Status Gizi) menunjukkan prevalensi angka stunting sebanyak 27,5\% kasus. ${ }^{4}$ Hal ini perlu diperhatikan karena menurut WHO apabila prevalensi balita stunting menunjukkan presentase $20 \%$ atau lebih, ini berarti sudah menjadi sebuah masalah kesehatan masyarakat karena dengan adanya kejadian stunting menunjukkan bahwa daerah tersebut memiliki masalah gizi kronis yang perlu dipantau. ${ }^{5}$ Di Kota Semarang pada tahun 2015 menunjukkan prevalensi kejadian balita stunting sebesar $11 \%$, namun pada tahun 2016 terjadi peningkatan kejadian menjadi $12,42 \%$, dan salahsatu puskesmas yang memiliki kasus terbanyak yaitu pada balita di wilayah kerja Puskesmas Pegandan yang ditunjukkan dengan 39 kasus dengan 5 kasus pada usia 0-11 bulan dan 34 kasus pada usia 12-59 bulan pada tahun $2017 .{ }^{6}$

Stunting merupakan salah satu masalah gizi kronis yang dapat menyebabkan gagal tumbuh pada balita sehingga anak cenderung lebih pendek dari anak usianya, serta berpeluang akan terjadi kelemahan perkembangan motoric, bahasa, sosioemosional, dan perkembangan adaptif., Kita ketahui bahwa pada usia balita merupakan golden age karena pada usia tersebut merupakan penentu untuk pembentukkan kualitas seseorang mulai dari petumbuhan fisik sampai dengan kecerdasan otak, sehingga perlu adanya pemantauan tumbuh kembang balita yang khusus dan optimal.

Salahsatu pemantauan status gizi balita yang strategis yaitu dengan adanya posyandu balita dan kader sebagai pendamping dan pendukung orangtua dalam memotivasi pentingnya memantau BB (berat badan) dan PB/TB (Panjang/Tinggi Badan) balitanya. Proses pencatatan dan pelaporan hasil penimbangan merupakan salah satu upaya dalam pengawasan atau monitoring dan pengendalian yang dapat dilakukan oleh kader posyandu dan juga dapat diketahui oleh puskesmas. ${ }^{1,9}$ Dengan adanya kerja sama yang baik diantara masyarakat, kader posyandu, dan pihak puskesmas dapat mendukung perolehan data yang akurat, lengkap, dan benar. Karena dengan adanya data tersebut dapat digunakan sebagai suatu pendukung keputusan dan perencanaan untuk kegiatan pembinaan gizi diwilayahnya. ${ }^{9}$

Berdasarkan studi pendahuluan, terdapat beberapa permasalahan terkait pencatatan dan pelaporan status gizi balita di kelurahan Gajahmungkur yang berjalan saat ini. Yang mana setiap posyandu di Kelurahan Gajahmungkur pada saat ini menggunakan sistem informasi secara manual sehingga membutuhkan waktu yang lama terkait pelaporan hasil penimbangan balita, hal ini dapat berpengaruh terhadap keterlambatan penemuan kasus stunting.

Maka dari itu perlu adanya pengembangan sistem informasi yang baru guna memantau pencatatan dan pelaporan terkait dengan rekapitulasi data status gizi 
balita dalam penatalaksanaan kasus stunting, sehingga kader posyandu maupun puskesmas dapat memantau secara real time/tepat waktu terhadap jumlah kasus yang terjadi di daaerahnya.

\section{METODE PENELITIAN}

Metode penelitian yang digunakan dalam pengembangan sistem informasi yaitu dengan FAST (Framework for the Application of System Techniques) yaitu dengan definisi lingkup, analisis permasalahan, analisis kebutuhan, desain logis, analisis keputusan, perancangan sistem, dan pembangunan sistem baru. ${ }^{10,11}$ Desain penelitian yang digunakan yaitu Action Research yang sesuai dengan hasil akhir dalam penelitian ini yaitu memecahkan masalah dalam situasi sosial diikuti melibatkan orang-orang yang ada di lokasi penelitian. ${ }^{12,13}$ Pendekatan dalam penelitian ini menggunakan pendekatan cross sectional karena data diukur dan dikumpulkan secara bersamaan. ${ }^{14}$ Subjek penelitian terdiri dari 1 Petugas KIA dan Gizi Puskesmas Pegandan, 1 Bidan Pembina wilayah Kelurahan Gajahmungkur, 13 kader posyandu balita Kelurahan Gajahmungkur (dengan dibagi 2 tahap yaitu; pertama subjek pengembangan sistem berjumlah 1 orang perwakilan dari masing-masing posyandu untuk proses analisis masalah dan analisis kebutuhan, dan yang kedua berupa 13 orang sebagai subjek penerapan sistem). Subjek penelitian ini dipilih berdasarkan keterkaitan langsung dalam penggunaan sistem informasi pencatatan dan pelaporan status gizi balita diwilayah Kelurahan Gajahmungkur.
Pengumpulan data dilakukan dengan observasi dan wawancara mendalam terhadap pengguna sistem informasi. Analisis yang digunakan yaitu analisis data kualitatif dilakukan dengan analisis isi yang berasal dari hasil wawancara mendalam dan observasi.

\section{HASIL DAN PEMBAHASAN}

Gambaran Umum dan Permasalahan Sistem Informasi Pencatatan dan Pelaporan Status Gizi Balita Stunting di Kelurahan Gajahmungkur Wilayah Kerja Puskesmas Pegandan

Sistem informasi pencatatan dan pelaporan status gizi balita stunting di Kelurahan Gajahmungkur wilayah kerja puskesmas Pegandan masih menggunakan sistem manual. Kader posyandu mencatatan hasil penimbangan balita di buku bantu penimbangan dan kemudian merekap serta menulis kembali di formulir laporan yang diberikan kepada petugas KIA dan Gizi puskesmas. Laporan rekapitulasi yang dilaporkan setiap bulannya hanya berisi data SKDN saja. Laporan yang diterima oleh petugas KIA dan Gizi puskesmas kemudian direkap kembali, diolah, dan dianalisis lalu dilanjutkan pelaporan ke Dinas Kesehatan Kota.

Berdasarkan gambaran tersebut, kader posyandu dan petugas KIA dan Gizi puskesmas mempunyai beban ganda dalam proses pencatatan untuk pelaporan hasil penimbangan. Sehingga masih ditemukannya beberapa permasalahan pada sistem informasi pencatatan dan pelaporan status gizi balita stunting sebelum dikembangkan yaitu terdapat ketidak validan 
data yang diberikan dalam pencatatan dikarenakan masih menulis secara manual, sering terjadi keterlambatan pelaporan oleh kader posyandu, laporan data hasil penimbangan yang dilaporkan hanya SKDN saja dan tidak per nama balita sehingga penyajiannya kurang lengkap, serta kesulitan mencari data apabila dibutuhkan saat tertentu dan disaat mendesak.

\section{Pengembangan Sistem Informasi Pencatatan dan Pelaporan Status Gizi Balita Stunting di Kelurahan Gajahmungkur Wilayah Kerja Puskesmas Pegandan}

Permasalahan yang terdapat pada sistem informasi pencatatan dan pelaporan status gizi balita stunting yang lama dapat diatasi dengan dilakukannya sebuah pengembangan sistem. Pengembangan sistem merupakan kegiatan penyusunan sistem baru untuk mengganti sistem lama secara menyeluruh atau memperbaiki sistem yang telah berjalan. ${ }^{15}$ Penelitian ini melaksanakan pengembangan sistem informasi yang terkomputerisasi serta menggunakan sistem manajemen basis data yang dapat memudahkan pengguna dalam mengakses data serta informasi.

Proses pengembangan sistem melalui tahapan perencanaan, penerapan atau implementasi sistem, pengoperasian serta pemeliharaan. Sistem yang sudah dikembangkan masih menemui permasalahan yang tidak dapat diatasi pada tahap pemeliharaan, maka proses pengembangan sistem kembali ke tahap awal. Siklus ini disebut dengan siklus hidup suatu sistem (systems life cycle). ${ }^{16}$

Sistem informasi yang akan dikembangkan sesuai dengan prosedur pemenuhan kebutuhan input, process, dan output pengguna. Pengembangan sistem informasi pencatatan dan pelaporan status gizi balita stunting ini berbasis responsive web dan dapat diakses melalui handphone android secara online. Pengembangan sistem informasi ini menggunakan bahasa pemograman PHP (Hypertext Prepocesor) dan basis data menggunakan $M y S Q L$.

Hal ini digunakan untuk meminimalisir proses keterlambatan pelaporan kader posyandu kepada petugas KIA dan Gizi puskesmas guna mendukung monitoring status gizi balita.

Sistem Informasi Pencatatan dan Pelaporan Status Gizi Balita Stunting di Kelurahan Gajahmungkur Wilayah Kerja Puskesmas Pegandan setelah Dikembangkan

Pengguna Sistem informasi yang dikembangkan ini yaitu Kader posyandu/bidan pembina wilayah dan petugas Kia dan Gizi puskesmas. Berikut merupakan diagram konteks sistem informasi pencatatan dan pelaporan status gizi balita stunting yang dapat dilihat pada Gambar 1, 
Gambar 1. Diagram Konteks SIstem Informasi Pencatatan dan Pelaporan status gizi balita stunting "MOZITA”(Baru)

Gambar 2. DFD Level 0 Sistem Informasi Pencatatan dan Pelaporan Status Gizi Balita Stunting "MOZITA"

Tabel 1 Output Sistem Informasi Pencatatan dan Pelaporan Status Gizi Balita di Kelurahan Gajahmungkur Wilayah Kerja Puskesmas Pegandan setelah Dikembangkan

\begin{tabular}{cllll}
\hline No. & \multicolumn{1}{c}{ Nama Output } & \multicolumn{1}{c}{ Format } & \multicolumn{2}{c}{ Media } \\
\hline 1. & $\begin{array}{l}\text { Laporan hasil penimbangan } \\
\text { balita }\end{array}$ & Tabel & Kertas & \\
\hline 2. & Early warning system & Tabel & $\begin{array}{l}\text { Komputer } \\
\text { android }\end{array}$ & atau \\
\hline 3. & Perkembangan balita & Grafik & $\begin{array}{l}\text { Komputer atau } \\
\text { android }\end{array}$ & \\
\hline
\end{tabular}

*Laporan yang dihasilkan oleh sistem informasi pencatatan dan pelaporan status gizi balita berdasarkan dari formulir laporan operasi timbang balita yang digunakan oleh puskesmas dan kader posyandu Kelurahan Gajahmungkur.

Output Yang Dihasilkan oleh sistem
Output yang dihasilkan oleh sistem informasi pencatatan dan pelaporan status 
gizi balita stunting "Mozita" dapat dilihat pada tabel 1. Tampilan output tersebut merupakan hasil dari wawancara mendalam yang dilakukan peneliti dengan pengguna sistem, sehingga dapat memenuhi kebutuhan.

a. Laporan Hasil Penimbangan balita

Output tersebut disajikan dalam tabel yang mana dapat di ekport kedalam excel dan dapat disimpan di device masingmasing pengguna. Laporan dibuat secara otomatis berdasarkan hasil pemasukan data hasil penimbangan balita oleh kader posyandu.

\section{b. Early Warning System}

Early Warning System merupakan keluaran atau hasil dari sistem berupa peringatan dini. Sistem peringatan dini merupakan sebuah sistem yang mudah untuk dirancang serta digunakan. Sistem ini membantu user untuk mengidentifikasi permasalahan lebih awal sehingga lebih menguntungkan serta dapat mengelola resiko lebih awal. Keuntungan lain dengan penerapan sistem ini adalah dapat membantu keuangan karena dapat meminimalisir penyelasaian permasalahan yang terlalu lama baru disadari. ${ }^{17,18}$

Pada output sistem di penelitian ini ditampilkan berupa tabel dan notifikasi apabila terdapat hasil penimbangan balita yang terindikasi mempunyai masalah status gizi, sehingga kader posyandu maupun petugas KIA dan Gizi puskesmas dapat memantau dengan cepat siapa saja nama balita yang bermasalah untuk mendukung perencanaan intervensi yang akan dilakukan selanjutnya.

c. Perkembangan Balita
Output perkembangan balita ini disajikan dengan grafik garis pada tampilan computer ataupun handphone android guna melihat perkembangan hasil penimbangan balita. Hasil penimbangan balita ini disesuaikan dengan indeks antropometri yang merupakan sebuah indeks gabungan diantara beberapa antropometri yang digunakan yaitu BB/U, TB/U, BB/TB, dan IMT/U. ${ }^{19,20}$

\section{Uji coba Sistem Yang Telah Dikembangkan}

Uji coba sistem informasi pencatatan dan pelaporan status gizi balita stunting "mozita" dilakukan pada petugas kia dan gizi puskesmas, bidan Pembina wilayah, dan kader-kader posyandu di Kelurahan Gajahmungkur wilayah kerja Puskesmas Pegandan. Sebelum dilakukan uji coba terlebih dahulu diberikan sosialisasi terkait pengembangan sistem informasi yang baru berupa cara penggunaan sistem aplikasi dan manfaat yang didapatkan dari penggunaan sustem informasi yang baru. Sosialisasi dan pelatihan dilakukan dengan cara mengumpulkan seluruh pengguna di Puskesmas Pegandan.

Berdasarkan hasil wawancara dengan Petugas KIA dan Gizi serta Bidan Pembina wilayah, informasi yang dihasilkan oleh mozita, terdapat adanya peningkatan dalam hal ketepatan waktu pelaporan pada sistem yang dikembangkan dapat membantu mengatasi permasalahan yang muncul dari pada sistem yang lama. Hal ini didukung dengan pernyataan sebagai berikut;

Petugas $\quad$ KIA
Puskesmas: “...dengan ini laporan bisa
langsung kita lihat setelah kader-kader


memasukkan data, jadi ndak perlu nunggu lama-lama .."

Bidan Pembina Wilayah: “...membantu mba, jadi saya ndak perlu ngejar-ngejar kader lagi, kalau sistem ini bisa digunakan seterusnya.."

Selain itu, pada pengembangan sistem ini setelah diujicobakan menunjukkan adanya peningkatan dalam kemudahan akses dalam membantu mengatasi masalah yang ada. Berikut kutipan wawancara yang mendukung pernyataan tersebut;

\section{Petugas KIA dan Gizi Puskesmas:} “..lumayan mudah di mengerti dan dipahami mba kalau dipelajari lebih lanjut, pake hape juga jadi bisa dipakai dimana aja.."

Bidan Pembina Wilayah: “...sistemnya termasuk mudah digunakan dan dipahami mba, tapi kalau bisa dibuatkan offline nya supaya kalau sinyalnya gak kuat bisa tetap masuk ke aplikasinya.."

\section{KESIMPULAN}

Pengembangan sistem informasi pencatatan dan pelaporan status gizi balita stunting ini dapat diakses online melalui komputer dan handphone android, sehingga proses pencatatan dan pelaporan dapat dilakukan secara akurat, cepat, dan mudah digunakan kapan saja serta dimana saja, guna dapat membantu monitoring status gizi balita dan pengambilan keputusan pada tingkat manajerial.

\section{UCAPAN TERIMAKASIH}

Peneliti mengungkapkan rasa terimakasih kepada pihak Puskesmas Pegandan yaitu kepala petugas KIA dan Gizi serta Bidan Pembina wilayah kelurahan Gajahmungkur, serta para kader posyandu kelurahan Gajahmungkur ata kontribusi dan kesediaannya dalam penerimaan pengembangan sistem informasi pencatatan dan pelaporan gizi balita yang baru.

\section{DAFTAR PUSTAKA}

1. Kesehatan K. Situasi Balita Pendek. Jakarta: Pusdatin; 2016.

2. Supariasa. Penilaian Status Gizi. Jakarta: EGC; 2001.

3. Organization WH. Nutrition Landscape Information System (NLIS) Country Profile Indicators: Intrepretation Guide. In: WHO, editor. Genewa2010.

4. Kemenkes. Penyajian Pokok-Pokok Hasil Riset Kesehatan Dasar 2013. Jakarta: Balitbangkes; 2013.

5. Kemiskinan TNPP. 100 Kabupaten/Kota Prioritas Untuk Intervensi Anak Kerdil (Stunting). Jakarta: TNP2K; 2017.

6. Semarang DK. Laporan Program Perbaikan Gizi Masyarakat. Semarang: DKK Semarang; 2017.

7. Depkes RI. Profil Kesehatan Indonesia 2005. Jakarta: Depkes; 2007.

8. Nasional KPP. Rencana Program Jangka Menengah (RPJM) 2015-2019. PP Nomor 2 Tahun 2015. Jakarta2015.

9. Pantaleon MG HH, IL G. Stunting Berhubungan Dengan Perkembangan Motoric Anak di Kecamatan Sedayu Bantul Yogyakarta. Jurnal Gizi dan dietetik Indonesia. 2015;3(1):9.

10. Whitten JL, LD B. System Analysis and Design Methods 7th Ed. New York: Mc Graw Hill; 2007. 
11. Kristanto, Andri. Perancangan Sistem Informasi dan Aplikasinya. Yogyakarta: Gava Media; 2003.

12. Mulyanto. Sistem Informasi Konsep dan Aplikasi. Yogyakarta: Pustaka Pelajar.

13. Yauimi M., M D. Action Research: Teori, Model, dan Aplikasi, Ed. 1. . Jakarta: Kencana Pranadamedia Group; 2014.

14. Lusiana., Novita. Buku Ajar Metodologi Penelitian Kabidanan. Ed 1. Yogyakarta: Deepublish; 2015.

15. Maniah. Analisis dan Perancangan Sistem Informasi: Pembahasan Praktis dengan Contoh Kasus Cetakan I. Yogyakarta: Deepublish; 2017.

16. Hartono, Jogiyanto. Analisis dan Desain Sistem Informasi Pendekatan Terstruktur Teori dan Praktek Aplikasi Bisnis. Yogyakarta: Andi; 2005.

17. Genocideprevention, Freswater. Early Warning Systems. [Internet]. 2003. [diakses pada tanggal 31 Januari 2019] Dari: http://www.genocideprevention.org/earlyw arning.htm

18. Triasih N. Penerapan Early Warning System untuk Pengendalian Obat, Studi Kasus: Unit Farmasi di RSUD Pekanbaru. Pekanbaru: UIN Sultan Syarif Kasim; 2010.

19. Kementerian Kesehatan Republik Indonesia. Standar Antopometri Penilaian Status Gizi Anak. Jakarta: Kemenkes; 2010.

20. Supariasa. Penilaian Status Gizi. Jakarta: EGC; 2002. 